\title{
Improving the adaptability of apricot to abiotic environmental factors
}

\author{
Anatolij N. Minin ${ }^{1,}$, Galina K. Markovskaya ${ }^{1}$, Elena H. Nechaeva ${ }^{1}$, Yuliya V. Stepanova ${ }^{1}$, and Nikolaj N. Hohlov ${ }^{2}$ \\ ${ }^{1}$ Samara State Agrarian University, 446442 Kinel, Samara region, Russia \\ ${ }^{2} \mathrm{Sad}$ OOO, 445556 Sadovyj, Samara region, Russia
}

\begin{abstract}
As a result of many years of breeding work on interspecific and intersortial hybridization in the Samara region, 9 apricot varieties were created and submitted for state testing, of which 4 varieties were entered into the state register of the Russian Federation. In the organic dormancy phase, apricot trees of these hybrids have high frost resistance of wood and flowering buds. Favorable microzones for apricot cultivation were determined, the productivity of varieties was studied, and the fruit quality was assessed. Of the 8 years of observing apricot, six years were fruitful. Two years of harvest was absent due to freezing of flower buds from the onset of frost after prolonged thaws. Samarskij (32.2 kg from a tree), Vnuchok (43.4 $\mathrm{kg})$ and Elita No. $1(24.9 \mathrm{~kg})$ sorts have high productivity. Ripening dates, weight and taste of apricot fruits depend on the variety, air temperature and the amount of precipitation. Large fruits are possessed by new varieties - Avdeevskij, Andryushka, Andryushka, Bojcovyj, Seyanec Voenkomovskij. The best tastes were of the varieties Andryushka, Bojcovyj, Seyanec Voenkomovskij, Trofej (tasting score 4.5 points).
\end{abstract}

\section{Introduction}

Apricot is a valuable stone fruit culture that is in great demand among the Russian population. Apricot trees are characterized by early maturity, productivity, high marketable and taste qualities of fruits. This is due to the good taste of the fruits of this culture and its great importance for human health.

They ripen at a time when there are no fruits of other crops, filling the gap between the end of fruiting of cherries and the beginning of ripening of summer varieties of apples and pears. Unfortunately, apricot is a crop, most varieties of which bear fruit unstable. The main disadvantage of European varieties, when they are cultivated in the middle zone of fruit growing, is the low winter hardiness of wood and especially flower buds.

After the first severe winter, trees of these varieties freeze strongly. In a sharply continental climate in the Middle Volga region, apricot trees are short-lived and do not bear fruit regularly. Therefore, attempts to cultivate southern apricot varieties in the middle lane always fail. Even I.V. Michurin strove to "immobilize" the apricot and move it far north.

At the beginning of the last century, he wrote and sowed apricot seeds from northeastern China and Mongolia, from which varieties Sacer and Mongol were obtained. Later, from the seeds obtained from Blagoveshchensk, the varieties Luchshij michurinskij and Tovarishch were obtained. Thus, I.V. Michurin created the first frost-resistant apricot varieties, which subsequently served as the initial forms in breeding for the cultivation of new varieties with fruits of better quality.

In recent years, focused work on apricot breeding has been carried out in many scientific institutions in the middle and northern areas of fruit growing. Breeders in Khabarovsk [1], in Saratov [2], in Moscow [3], in Khakassia [4, 5], in Irkutsk [6], in Orel [7] with the hybridization of frost-resistant varieties of Manchurian and Siberian were bred for these areas of fruit growing. In Orenburg [8-12], as a result of analytical selection, fruitful and large-fruited hybrid apricot forms of the local population were selected.

Thus, thanks to the breeding work of Soviet and Russian scientists on interspecific hybridization of apricot, this culture has advanced far north today. However, here the apricot does not have industrial value and it is grown only in amateur gardening. Small apricot plantings are found in the Black Earth Region, in the Non-Chernozem Region, in the Lower and Middle Volga Region, in the Southern Urals, in the Far East and even in Siberia - in the most favorable microzones.

Apricot in the Middle Volga region is a new crop, and its cultivation was made possible as a result of interspecific hybrids of common apricot with Manchurian and Siberian varieties.

Samara breeders also sought to create adaptive varieties of this culture [13-16]. As a result of work in the State Register of selection achievements of the Russian Federation, 4 apricot varieties of Samara selection were included - Kujbyshevskij Yubilejnyj, Pervenec Samary, Samarskij i Yantar of the Volga Region. The other 5 varieties - Valentine, The Pearl Of

Corresponding author: iv-minina@yandex.ru 
The Zhiguli, Zhigulenok, Sokol and Trofej are transferred and pass the state variety test. In 2019, new elites of apricot are transferred for state testing Avdeevskij, Andryushka and Gnomik. All this huge work speaks of the importance and prospects of selection for the purpose of breeding winter-hardy apricot varieties that can bear fruit in harsh climatic conditions.

In this regard, a comprehensive economic and biological assessment of the available breeding material with the aim of its further propagation and introduction into production is of particular relevance.

The purpose of research is the creation of apricot varieties capable of stably bearing fruit in the conditions of the forest-steppe of the Middle Volga.

We have set the following tasks:

- at the initial stage of work, evaluate the agroecological potential of individual agroclimatic regions of the Samara region and identify the most favorable areas for cultivating an apricot culture;

- conduct an expeditionary survey of apricot varieties in these areas and select the best ones for propagation by analytical selection;

- using the interspecific hybridization method, create your own apricot varieties capable of bearing fruit under stressful conditions of the Middle Volga;

- to study the economic and biological characteristics of the created apricot varieties according to the most important indicators: winter hardiness, productivity, taste and technological qualities of fruits.

\section{Materials and methods}

Work on the selection and primary study of apricot varieties was carried out in 2011 - 2018 in the Samara State Agrarian University. The objects of research were 15 varieties and elites of apricot Samara selection. In the primary study, varietal samples are represented by $1-2$ uterine and grafted trees for winter-hardy plum varieties of home. Over the years, the following indicators were evaluated: productivity, timing of flowering and ripening of fruits, fruit quality. Phenological observations and counts were carried out in two regions of the region (the village of Zhigulevsky Gardens of the Kirov District and the Soksky Dawns cottage area of the Krasnoyarsk Region), which differed in climatic and soil conditions. Varieties in the collection were studied according to the program of variety studies of fruit, berry and nut-bearing crops [17].

The study, selection and transfer of hybrid seedlings to the state testing was carried out, guided by the method of selection of fruit, berry and nut crops [18]. The productivity of apricot varieties was taken into account on 8-12 year old trees in a visual way. Terms of fruit ripening were determined by the onset of consumer maturity of fruits. The average weight of the fruit was calculated by weighing at least 30 pieces of fruit in the sample for each variety. The yield was treated as onefactor experience with the double frequency and with the conversion of dates. The collected data was processed in a table processor Excel.

\section{Results and discussion}

Geographically Samara region occupies the Central part of the Middle Volga region and is located within two climatic zones - forest-steppe and steppe. The climate is sharply continental. The average annual temperature is $+2.9 \ldots+3,9^{\circ} \mathrm{C}$. In summer, the maximum temperature can reach $+40^{\circ} \mathrm{C}$ and even higher, and in winter in some years, the minimum temperature drops to $-40^{\circ} \mathrm{C} \ldots-45^{\circ} \mathrm{C}$ and below. This prevents the stable growth, development and fruiting of apricot trees.

The main factors limiting the successful growth of apricot in the region are: low minimum temperatures in winter; sudden changes in temperature in the form of thaws and subsequent frosts at the end of the winter period; frequent droughts in the spring, summer and autumn; return frosts, as well as hot dry weather, leading to disruption of the micro- and macrogametogenesis during flowering and ovary formation; damage to apricot trees with a monilial burn; often barking is observed in warm snowy winters.

For 70 years, in the Samara region as a result of selection and sowing of seeds, its own local population of interspecific hybrid forms was formed, in the origin of which ordinary, Siberian and Manchurian apricots participated.

The emergence of apricot culture and its shaping in the Samara region has its own history. The introduction and acclimatization of apricot in the Samara region for the first time in 1949 was undertaken by a researcher at the Kuibyshev Botanical Garden Otvinovskaya V.E. She received bones from scientific institutions of the former USSR and sowed in a farm.

Later, Avdeev V.S. in his work [19] pointed out that the harsh conditions of the sharply continental climate of the Middle Volga region made significant adjustments to the safety of hybrid offspring. Only a few seedlings reached fruiting. These preserved Sentsi were used in crosses as initial parental forms by V.A. Molchanov in 1964-1965 and second-generation hybrids were obtained, some of which were isolated into varieties Karlik, Kuibyshevsky Yubileiny, Kuybyshevsky Ranniy (Samara), Zhiguli (Trofej) [16]).

At the same time and until now, employees of the botanical garden actively distributed apricot seedlings among experienced gardeners. Most of these seedlings later died as a result of their freezing or heating of the cortex in the region of the root neck. Many of them have reached fruiting and give decent yields of fruits of different quality and different ripening times. As the history of their study showed, the origin of these seedlings involved parental forms of various ecological and geographical groups (Central Asian - Karlik, East Asian - Kujbyshevskij Yubilejnyj).

Later, as a result of crosses in 1989, we obtained about 500 third-generation apricot hybrid seedlings. Most of these seedlings again died as a result of the bark heating in the area of the root neck. Of the remaining hybrids brought to fruiting (the first fruiting in 2000), 5 hybrids were allocated to the elite. According to the initial variety testing (2000-2002), we identified 3 varieties that were recommended by the pomological 
commission for transfer to the state variety testing Samara (Kujbyshevskij Yubilejnyj X Kujbyshevskij Early), Zhemchuzhina Zhigulej (Kujbyshevskij Yubilejnyj X Karlik), Yantar Povolzhya (Karlik X Kujbyshevskij Yubilejnyj)

At present, there are more than 200 hybrids obtained from interspecific crosses, as well as free pollination of varieties of domestic selection, at the site of primary variety research. They are fourth-generation hybrids. At the same time, there is a collection of varieties and the best hybrid forms of other scientific institutions to replenish the collection. Great importance is attached to the collection and replenishment of the existing collection of other varieties of the genus Prunus with the further involvement of the latter in breeding work. The existing collection of apricot varieties is also replenished with the material of two or three hybrid generations coming from experienced gardeners.

At present, with the seed method of reproduction, a wide variety of hybrid forms of different winter hardiness has arisen, many specimens suffer from the heating of the bark of the stem. Mostly small-fruited forms with a fetal weight of 10 to $30 \mathrm{~g}$ prevail in the population. However, some forms already have a fetal mass of 30-35 g or more. Most of the shapes are yellow in color, with blurred dots and spots of red blush on the sunny side. Most fruits are slightly pubescent. Many hybrid forms with fibrous flesh, bitter taste. They inherited the bitter taste of the fruit from the Manchurian apricot, which strictly conveys this trait to hybrid offspring.

The seed core of Samara apricots is bitter. Productivity in hybrid forms and new varieties is unstable over the years and only in favorable years is it high. Instability in the crop is associated with the systematic freezing of flower buds due to a short dormant period. This trait is also clearly inherited from the Siberian and Manchurian varieties.

As a result of expeditionary surveys, the most favorable microzones for growing apricot were determined. This is the right bank of the Volga River; left bank - the suburbs of Syzran city, Oktyabrskr city; outskirts of Samara along the left bank of the river. Volga, the southern outskirts of Samara - suhaya Samarka, Grannyj village, as well as land at the confluence of Sok river and Volga river. Here apricot bears fruit almost regularly. Apricot is grown only in well-lit locations: western, south-western slopes on soils of light and medium texture.

Until the hard winter of 2009/10 30 varieties of apricot were in the primary study. Of the 30 varieties that winter, seven introduced varieties $(23.3 \%)$ of the apricot varieties were frozen. Five varieties (16.7\%) had an average and above average degree of freezing (3.5 4.5 points), many of which later also died. Eighteen cultivars $(60 \%)$ suffered a winter with freezes of 2.0 3.0 points, and only two varieties of apricot Samarskij and Yantar Povolzhya had minor frost damage (1.5 - 2.0 points). The main damage to the trees was the freezing of skeletal branches and the freezing of flowering buds.

It is known that the fruit tree harvest is planted in the previous year. Weather conditions in the summer- autumn period of 2010 were unfavorable for the laying and differentiation of flower buds in apricot. In summer and autumn, severe atmospheric and soil drought was observed. In such a stressful situation, many varieties of trees did not plant flower buds due to a large moisture deficit. Weather conditions for wintering in winter 2010/2011 initially developed favorably for apricot. However, in February, frosty weather set in with clear sunny days and frosty nights. As a result, swollen flower buds were badly damaged by frost and winter withers. Later, with the onset of warmer weather, they fell off. In 2011, the crop was observed only on the Vnuchok and Elita No. 1 varieties (Table 1).

Table 1. The productivity of apricot varieties for 2011-2018

\begin{tabular}{|c|c|c|c|c|c|c|c|c|}
\hline \multirow[t]{3}{*}{ Sample name } & \multicolumn{8}{|c|}{ Productivity, in $\mathrm{kg} / \mathrm{tr}$. on years } \\
\hline & 201 & 201 & 201 & 201 & 201 & 201 & Average & Average \\
\hline & 1 & 2 & 3 & 6 & 7 & 8 & variety & \\
\hline Avdeevskij * & & & & 19.0 & 1.0 & 14.0 & 11.3 & 11.3 \\
\hline Andryushka * & & & & 7.0 & 2.0 & 12.0 & 7.0 & 7.0 \\
\hline Bojcovyj & 0 & 4 & 6 & 6.0 & 2.0 & 12.0 & 5.0 & 6.7 \\
\hline Valentin & 0 & 5 & 37 & 17.0 & 3.5 & 24.0 & 14.4 & 14.8 \\
\hline Vnuchok & 46 & 56 & 80 & 30.0 & 0.5 & 48.0 & 43.4 & 26.2 \\
\hline Gnomik* & & & & 21.8 & 1.0 & 27.0 & 15.6 & 16.6 \\
\hline Karlik & 2 & 5 & 2 & 6.0 & 1.0 & 20.0 & 6.0 & 9.0 \\
\hline $\begin{array}{c}\text { Kujbyshevskij } \\
\text { Yubilejnyj } \\
\text { (control) }\end{array}$ & 0 & 2 & 3 & 8.0 & 3.0 & 30.0 & 8.0 & 13.7 \\
\hline Samarskij & 1 & 27 & 77 & 17.0 & 1.0 & 70.0 & 32.2 & 29.3 \\
\hline Sokol & 0 & 0.5 & 2 & 3.0 & 0.5 & 5.0 & 1.8 & 2.8 \\
\hline Trofej & 0 & 1 & 2.5 & 6.0 & 2.0 & 8.0 & 3.3 & 5.3 \\
\hline $\begin{array}{c}\text { Seyanec } \\
\text { Voenkomovski }\end{array}$ & 0 & 0 & 3.5 & 3.0 & 0.5 & 6.0 & 2.2 & 3.2 \\
\hline Sokskie Zori & 0 & 1 & 0.5 & 5.0 & 1.5 & 3.0 & 1.8 & 3.2 \\
\hline Elita №1 & 11 & 8 & 46 & 22.7 & 9.8 & 52.0 & 24.9 & 28.2 \\
\hline $\begin{array}{c}\text { Yantar } \\
\text { Povolzhya }\end{array}$ & 1 & 11 & 6 & 7.0 & 0.5 & 18.0 & 7.3 & 8.5 \\
\hline $\begin{array}{c}\text { Srednyaya po } \\
\text { godam }\end{array}$ & 5.1 & 10.0 & 22.1 & 11.9 & 2.1 & 23.3 & & \\
\hline
\end{tabular}

Varieties Karlik, Samarskij and Yantar Povolzhya gave single fruits. This year, no connection was found between the age of the trees and their productivity $(r=+$ $0.2261 *)$. It can be assumed that weather conditions had a greater effect on the lack of yield than age. In the next two years, the connection between fruiting and the age of trees was noticeable $-\mathrm{r}=+0.5341 *$ in 2012 and $\mathrm{r}=+$ $0.6374 *$ in 2013 . The correlation coefficient between productivity and age of trees is $+0.5567 *$. That is, mature trees provided a greater yield. Stone fruits are considered to be short-lived, especially in our area. During this test period, it was not possible to identify a negative connection between the longevity of apricot trees and their productivity. Varieties Valentin, Vnuchok, Elita №1, Samara showed good productivity.

The growing season of 2012 began 8 days earlier than the average multi-year terms. In May 2012 (during flowering and fruit setting), an increased temperature regime and a deficit of precipitation were observed. The flowering of the bulk of apricot varieties took place in hot, dry weather with frequent dry winds, which 
extremely negatively affected the fruit setting. Under such conditions, the stigmas of the pistils dried out quickly, and normal fertilization did not occur.

Weak flowering (2-3 points) was observed in the varieties Andryushka, Karlik, Sokol, Sokskie Zori, Trofej. Varieties Bojcovyj, Valentin, Kujbyshevskij Yubilejny blossomed for 4 points. Vnuchok, Samara, Elita №1, Yantar Povolzhya bloomed excellent (flowering 5 points).

In 2012, the correlation coefficient between productivity and the degree of flowering was $+0.59 *$. This means that $34 \%$ of variability in productivity by variety was caused by fluctuations in the degree of flowering. In 2013, this relationship was also positive, but weaker $(\mathrm{r}=+0.48 *)$. That is, in conditions more favorable for flowering, only $23 \%$ of the variation in yield is caused by differences in the degree of flowering of varieties.

In 2013, flowering in all varieties was plentiful (4-5 points). Most of the apricot varieties had a weaker crop in 2012 as a whole was weaker than in 2013.

In 2012, the harvest of Seyanec Voenkomovskij was absent from the elite; in 2013, the elite form of apricot Sokskie Zori did not have a harvest.

In 2014 and 2015, flowering was absent on all apricot varieties due to freezing of flower buds in the winter-spring period after thaws.

In the last three years of observation, especially severe winters have not been observed. Wintering conditions for apricot trees in winter 2015/2016 and during the flowering of the apricot developed very favorable.

In the Krasnoyarsk district, the apricots Karlik and Samarskij blossomed on April 23-24 at a relatively low air temperature in the daytime of $9-13{ }^{\circ} \mathrm{C}$. On April 2627, Valentine, Sokol bloomed. On April 26, the temperature during the day was $22{ }^{\circ} \mathrm{C}$.

In the Kirov region, flowering began 3-5 days later. On April 27, the varieties Andryushka, Bojcovyj, Sokskie Zori, Karlik bloomed, and the variety Trofej bloomed on April 30. Basically, all varieties had fairly good flowering. With the exception of the Sokskie Zori elite, its flowering rate was estimated at 3.5 points and is average. In the main group of varieties, flowering was good and was rated at 4 points. Varieties Vnuchok and Elita №1 had abundant flowering at 5 points.

Summer was quite dry and hot. In all months, the average temperature was above normal. All varieties and elite forms this year showed high productivity. Variance analysis of the crop proved the differences between the varieties. Varieties Avdeevskij, Gnomik, Valentin and Samarskij showed good productivity in 2016, and the minimum indices were Sokol and Seyanec Voenkomovskij.

According to surveys, 2016 is characterized by a very fruitful year. Autumn, on the contrary, was quite rainy. October was characterized by cool, cloudy weather throughout the month. December was the coldest, and in the second half of the winter of 2016/17 prolonged thaws were observed. In March, severe frosts came after thaws, especially at night.
They led to the death of flower buds, which dramatically affected the productivity of plants. Thus, the conditions of the autumn-winter period had a negative impact on the differentiation and preservation of flower buds. The weather conditions of spring and the first half of summer 2017 were very rainy and extremely negative for flowering and fruit setting. In 2017, most apricot varieties growing in the Krasnoyarsk region had no flowering. Trees of the varieties Avdeevskij, Samarskij, Gnomik, Karlik, Seyanec Voenkomovskij bloomed by $1.0-1.5$ points. Varieties located in the Kirovsky district - Andryushka, Bojcovyj, Trofej, Kujbyshevskij Yubilejnyj, Sokskie Zori — had an average degree of flowering (3-3.5 points).

The year 2017 was characterized as weak in productivity of the apricot culture. In many varieties, the crop was absent. On others, it was weak (from 1.0 to 2.0 $\mathrm{kg}$ per tree). Varieties Valentin and Kuibyshevsky Yubilejnyj showed slightly greater productivity this year.

The minimum air temperature in the winter of $2017 / 2018$ did not fall below $-30^{\circ} \mathrm{C}$. Frosts in January ($25 \ldots-30^{\circ} \mathrm{C}$ ) were preceded by shallow thaws, followed by moderately negative temperatures. The productivity of the studied variety samples in 2018 was also high, and for individual variety samples even higher than in 2016.

Thus, the analysis of the crop showed significant differences both by year and between apricot varieties. The highest productivity in an average of 8 years of observation was shown by the Samarskij variety, the Vnuchok elite and the Elita №1. New varieties Avdeevskij, Valentin, Gnomik have good productivity.

As a result of observations (2011-2018) and surveys of apricot varieties, it was revealed that due to freezing of flower buds in the second half of winter after prolonged thaws and the onset of subsequent frosts, the crop was missing twice - in 2014 and 2015.

Of the 6 years of fruiting, two years were especially fruitful (2013 and 2018). A weak crop and not on all varieties was observed in 2011 and 2017. Twice the harvest was average (2012 and 2016).

Ripening dates, weight and taste of apricot fruits varied from year to year depending on air temperature and the amount of precipitation. However, the sequence of the varieties in the dates of ripe fruit maturity was preserved. When comparing varieties among themselves in 2016-2018 (Table 2) the group with large fruits (Avdeevskij, Andryushka, Bojcovyj, Gnomik, Seyanec Voenkomovskij) and the group with small fruits Vnuchok, Karlik, Elita №1 were more clearly distinguished.

Since there were no sharp differences between the other groups, the group of medium-fruit varieties with fruit weight of 15-30 g included varieties and elites Valentin, Kujbyshevskij Yubilejnyj, Samarskij, Sokol, Trofej, Yantar Povolzhya.

The best varieties were distinguished by the varieties Andryushka, Bojcovyj, Seyanec Voenkomovskij, Trofej (tasting score 4.5 points). Most varieties (4.0 to 4.4 points) received an average taste rating. The taste is "below the average rating" in the varieties Karlik, Elita №1 (3.9 points). 
Table 2. Qualitative characteristics of apricot fruits for 20162018.

\begin{tabular}{|c|c|c|c|c|c|c|c|c|}
\hline Variety & \multicolumn{3}{|c|}{ Ripening period } & \multicolumn{3}{c|}{$\begin{array}{c}\text { Average fruit } \\
\text { weight, g }\end{array}$} & $\begin{array}{c}\text { The taste } \\
\text { of the fruit } \\
\text { (score) }\end{array}$ \\
\hline & 2016 & 2017 & 2018 & 2016 & 2017 & 2018 & 2016 & 2017 \\
\hline Avdeevskij & 17.07 & 25.07 & 22.07 & 26.3 & 27.0 & 31.8 & 4.2 & 4.3 \\
\hline Andryushka & 20.07 & 9.08 & 28.07 & 22.4 & 28.4 & 32.2 & 4.5 & 4.5 \\
\hline Bojcovyj & 21.07 & 11.08 & 6.08 & 25.4 & 28.4 & 31.2 & 4.5 & 4.4 \\
\hline Valentin & 17.07 & 28.07 & 24.07 & 22.0 & 23.8 & 23.9 & 4.0 & 4.0 \\
\hline Vnuchok & 27.07 & 4.08 & 10.08 & 14.4 & 24.2 & 14.3 & 3.8 & 4.0 \\
\hline Gnomik & 27.07 & 7.08 & 28.07 & 25.2 & 27.9 & 33.0 & 4.3 & 4.4 \\
\hline Karlik & 13.07 & 26.07 & 22.07 & 11.7 & 17.9 & 14.6 & 3.9 & 3.9 \\
\hline $\begin{array}{c}\text { Kujbyshevskij } \\
\text { Yubilejnyj }\end{array}$ & 11.07 & 25.07 & 23.07 & 19.4 & 22.9 & 25.6 & 4.5 & 4.3 \\
\hline Samarskij & 11.07 & 26.07 & 22.07 & 21.7 & 23.1 & 30.1 & 4.1 & 4.0 \\
\hline $\begin{array}{c}\text { Seyanec } \\
\text { Veenkomovskij }\end{array}$ & 21.07 & 1.08 & 28.07 & 25.9 & 31.0 & 33.7 & 4.5 & 4.5 \\
\hline Sokol & 17.07 & 3.08 & 19.07 & 17.9 & 25.6 & 27.7 & 4.1 & 4.2 \\
\hline Sokskie Zori & 19.07 & 4.08 & 20.07 & 16.8 & 18.8 & 19.2 & 4.0 & 4.0 \\
\hline Trofej & 21.07 & 9.08 & 3.08 & 23.2 & 27.8 & 29.0 & 4.5 & 4.5 \\
\hline Elita №1 & 5.07 & 26.07 & 22.07 & 9.8 & 28.5 & 11.3 & 4.0 & 3.9 \\
\hline $\begin{array}{c}\text { Yantar } \\
\text { Povolzhya }\end{array}$ & 27.07 & & 8.08 & 25.3 & & 28.8 & 4.0 & \\
\hline By year & $5.07-$ & $25.07-19.07-$ & 20.49 & 25.37 & 25.82 & & \\
\hline & 27.07 & 11.08 & 10.08 & & & & & \\
\hline
\end{tabular}

\section{Conclusion}

Ecological adaptation of apricot is severely limited. In the conditions of the Samara region, apricot is distributed only in areas with very specific environmental conditions favorable for climatic conditions for its cultivation. As a result of breeding work on interspecific hybridization of apricot, new, more adaptive varieties have been created that have high frost resistance of wood and flower buds during the period of organic dormancy. Varieties with high taste and technological properties were identified and recommended for propagation.

By involving other varieties of Siberian and Manchurian in the apricot hybridization, it was possible to solve an important problem - to significantly increase the frost resistance of wood and flowering buds in plants during the organic dormancy phase. In apricot breeding, the following two main tasks, in our opinion, of increasing resistance to abiotic environmental factors are still unresolved: the creation of varieties resistant to frost after thaws; the creation of varieties resistant to undermining of the bark of the stem in mild snowy winters.

\section{References}

1. G.T. Kazmin, V.A Marusich, Far Eastern Apricot (The Khabarovsk book publishing house, 1989)

2. A.M. Golubev, Apricot selection in Saratov Sady Rossii 1, 42-48 (2010)

3. A.K. Skvorcov, L.A. Kramarenko, Apricot in Moscow and Moscow region (Association of scientific publications KMK, Moscow, 2007)
4. I.L. Bajkalov, Gardeners of Siberia: Album-directory Abakan (Abakan, 2002)

5. T. Duskabilov, T.I. Duskabilova, E.I Piskunov, Apricot in the south of Central Siberia (Russian Academy of Agricultural Sciences. Siberian branch. State Scientific Institution Scientific Research Institute of Agrarian Problems of Khakassia, Russian Academy of Agricultural Sciences, Novosibirsk, 2004)

6. T.V. Eremeeva, Gardens of Cisbaikalia (Irkutsk, 2007)

7. E.N. Dzhigadlo, A.A. Gulyaeva, Improving the range of stone fruits in central Russia Electronic J. of Modern Gardening 3, 1-18 (2013)

8. V.I. Avdeev, Modern centers of origin of northern apricot in Eurasia Electronic J. 3, 22-27 (2012) Retrieved from: http://www.vestospu.ru

9. V.I. Avdeev, A.Zh. Saudabaeva, The genetic pool of local apricot Orenburg region (Cisurals) The bulletin of the Orenburg State Agrarian University 2, 234-238 (2011)

10. A.Zh. Saudabaeva, Form diversity in the southeast, molecular biological characteristics of Armeniaca scop. Orenburg region. The abstract of a candidate thesis (Orenburg, 2013)

11. E.P. Starodubceva, Composition, classification of local forms of Armeniaca scop. Orenburg Urals. The abstract of a candidate thesis (Orenburg, 2012)

12. V.V. Shmygareva, Shaped variety cultivated by Armeniaca scop. in the east of the Orenburg Urals. The abstract of a candidate thesis (Orenburg, 2011)

13. A.V. Bronnikov, A.N. Minin, Some results of the study of apricot variety in the Samara region Fruit growing and berry growing in Russia XXXIX, 3637 (2014)

14. A.N. Minin, Apricot selection for frost resistance in the Samara region Fruit growing and berry growing in Russia 31(2), 73-77 (2015)

15. A.N. Minin, E.H. Nechaeva, N.A. Melnikova, Apricot selection and cultivation in the forest-steppe of the Middle Volga The Bulletin of the Samara State Agricultural Academy 2, 3-7 (2016)

16. V. A. Molchanov, Apricots of the Middle Volga (Parus-Print, Samara, 2004)

17. Program and methodology for selection of fruit, berry and nut-bearing crops (Publishing house VNIISPK, Oryol, 1995)

18. Program and methodology for selection of fruit, berry and nut-bearing crops (Publishing house VNIISPK, Oryol, 1999)

19. V. S. Avdeev, Some results of the acclimatization of apricot In Introduction and acclimatization of ornamental and cultivated plants 109, 46-61 (Kuibyshev, KSU, 1973) 